\title{
Improvement of carbon dioxide removal through artificial light intensity and temperature by constructed green microalgae consortium in a vertical bubble column photobioreactor
}

\author{
Astri Rinanti $^{1}$, Edwan Kardena ${ }^{{ }^{\star}}$, Dea Indriani Astuti ${ }^{2}$, Kania Dewi ${ }^{1}$ \\ ${ }^{1}$ Faculty of Civil and Environmental Engineering, Bandung Institute of Technology, Indonesia. Jl. Ganesha No. 10, \\ Bandung 40132. \\ ${ }^{2}$ School of Life Sciences and Technology, Bandung Institute of Technology, Indonesia.Jl. Ganesha No. 10, Bandung \\ 40132. \\ Email:kardena@pusat.itb.ac.id
}

Received 15 August 2013 Received in revised form 3 October 2013; Accepted 7 October 2013

\begin{abstract}
Aims: This study was aimed to demonstrate that environmental conditions, such as light intensity, photoperiodism and temperature, played a determining role in improving $\mathrm{CO}_{2}$ removal and cellular propagation. Photosynthesis by microalgae in a direct $\mathrm{CO}_{2}$ to biomass conversion in engineered systems such as photobioreactors, has been frequently used for $\mathrm{CO}_{2}$ removal. The goal of this study was to obtain high $\mathrm{CO}_{2}$ removal by green microalgae strains cultivated in a vertical bubble column photobioreactor.

Methodology and results: Constructed consortium containing Chlorella sp., Scenedesmus obliquus, and Ankistrodesmus sp. were cultured in temperatures $\left({ }^{\circ} \mathrm{C}\right.$ ) of $25,30,25$; light intensities (lux) of 2500 , 4000 and photoperiodisms (light/dark; hour) of 24/0, 16/8, and 12/12. The experiment demonstrated that microalgae was capable of tolerating up to $7 \% \mathrm{CO}_{2}$ concentrations under variation of light intensities, photoperiodisms, and temperature conditions. Synergetic of three microalgae capable of utilizing $\mathrm{CO}_{2}$ and transformed it to become biomass. The result also showed that growth was best at light intensity of 4000 lux for $16 \mathrm{~h}$ a day and temperature of $30^{\circ} \mathrm{C}$. The maximum growth rate $(\mu)$ of 0.38 per day was obtained from culture injected with $5 \% \mathrm{CO}_{2}$ concentration.

Conclusion, significance and impact study: The $\mathrm{CO}_{2}$ removal efficiency (\%) was 49.02, whereas $\mathrm{CO}_{2}$ utilization efficiency $(\%)$, carbon dioxide transfer rate $\left(\mathrm{CTR} ; \mathrm{gCO}_{2} / \mathrm{L} . \mathrm{h}\right)$ and carbon dioxide fixation rate $(\mathrm{qCO} / \mathrm{h}) \mathrm{were} 15.15$, 101.29 and 42.02, respectively. Biofixation of $\mathrm{CO}_{2}$ by the constructed consortium has recently gained renewed interest as a promising strategy for $\mathrm{CO}_{2}$ mitigation.
\end{abstract}

Keywords: light intensity, photoperiodism, $\mathrm{CO}_{2}$ removal, $\mathrm{CO}_{2}$ fixation, biomitigation

\section{INTRODUCTION}

Carbon fixation by photoautotrophic microalgae has the potential to diminish the release of $\mathrm{CO}_{2}$ into the atmosphere and helping to alleviate the trend toward global warming. In order to obtain a higher $\mathrm{CO}_{2}$ removal efficiency, high-density cultivation was performed. Under these conditions, more $\mathrm{CO}_{2}$ will be consumed by the microalgae.

Association of microalgae culture seems a promising technology for sustainable algal biomass and biological removal of carbon dioxide. Our previous study concluded that single culture as well as mixed culture could tolerate live and grew well in high $\mathrm{CO}_{2}$ concentration due to indications of dry biomass and growth rate. However, mixed culture has higher removal efficiency of $\mathrm{CO}_{2}$ than single culture of Chlorella sp. Scenedesmus obliquus, and Ankistrodesmus sp. (Rinanti et al., 2013).

The most important environmental factor for the growth of photosynthetic unicellular microalgae is light.
Light provides energy for the photoautotrophic process. Concerning light intensity, operational issues are not yet clear cut. On one hand, the use of sunlight is cheaper but light cycle cannot be controlled, which often precludes higher biomass productivities. However, the quality and duration of light to which the algae are exposed in the natural environment is not always available at the best conditions for the optimum growth of the algae.

On the other hand, artificially illuminated photobioreactors are typically expensive. The intensity and utilization efficiency of the light supplied are thus of crucial importance in microalgae bioreactors (Kumar et al., 2010). The growth of microalgae, which is also photosynthetic, is controlled by both the spectral quality and quantity of the light source and the length of daylight (Striebal et al., 2009). Photosynthesis is the production of organic compounds (including carbohydrates, proteins, and lipids) using inorganic substances (such as carbon dioxide and water). This process involves the conversion of light energy into chemical energy. Chemical 
substances called pigments absorb light. The main pigment used to absorb light in photosynthesis is chlorophyll. Carbon dioxide is absorbed for photosynthesis.

For the $\mathrm{CO}_{2}$ fixation and biomass production optimum light intensity is necessary. Below the optimum light intensity, light becomes the limiting factor for the microalgae productivity. On the other hand, exposure of cells to long period with high light intensity causes photoinhibition (Rubio et al., 2003). Masojideck et al. (2011) also described phenomenon of photoinhibition. Under prolonged irradiation at a supra-optimal level, photosynthetic rates usually decline from their lightsaturated values. A further rise in light intensity to above 8000 lux did not make much difference to either the growth rate or the dry weight of the microalgae, suggesting that a light saturation point had been reached. Saturation light intensity roughly varies from 30 to 45 $\mathrm{W} / \mathrm{m} 2\left(140-210 \mu \mathrm{E} / \mathrm{m}^{2} . \mathrm{s}^{1}\right)$ with a good estimation. For example, according to Hanagata et al. (1992) saturation light intensity of Chlorella sp. and Scendesmus sp. is around $200 \mu \mathrm{E} / \mathrm{m}^{2}$. $\mathrm{s}^{1}$. The ratio of light to dark (or lowintensity light) periods in a cycle is crucial for microalgae productivity (Muñoz and Guieysse, 2006).

Temperature is the most important limiting factor, after light, for culturing algae in both close and open outdoor systems that regulate cellular, morphological and physiological responses of microalgae (Vonshak et al., 2001; Carlozzi, 2003; Moheimani, 2005; Chisti, 2007). Higher temperatures generally accelerate the metabolic rates of microalgae, whereas low temperatures lead to inhibition of microalgae growth (Muñoz and Guieysse, 2006). The optimum growth temperature of most microalgae is in the range of $20-30{ }^{\circ} \mathrm{C}$ (Wang et al., 2008). When the temperature is much lower or much higher than the optimum, specific growth rate of microalgae is reduced (Madigan et al., 2000; Thébault et al., 2003).

The goal of the study was to obtain high $\mathrm{CO}_{2}$ removal by green microalgae consortium cultivated in a vertical bubble column photobioreactor that are capable of tolerating up to $7 \% \mathrm{CO}_{2}$ (gas phase) concentrations under variation of light intensity, light photoperiodism (light/dark), and temperature.

\section{MATERIALS AND METHODS}

\section{Microorganisms and growth medium}

The microalgae consortium consists of 3 green microalgae Chlorella sp., Scenedesmus obliquus and Ankistrodesmus sp. with the same density ratio, isolated from Bojong Soang Municipal Waste Water Treatment Plant. Activation and cultivation carried out in sterilized artificial medium Phovasoli Haematococcus Media (PHM) (Provasoli and Pintner, 1960), the $\mathrm{pH} 7+0.5$.

\section{Cultivation and growth conditions in a vertical photobioreactor}

A vertical photobioreactor made of glass with a capacity of $10 \mathrm{~L}$ containing $8 \mathrm{~L}$ of artificial growth medium for microalgae consortium cultivation. To achieve the objectives of this study, photobioreactor equipped with a source of gas from $\mathrm{CO}_{2}$ gas cylinder and aerator. Pure $\mathrm{CO}_{2}$ was injected from the bottom of the column to allow gas mixing with the medium. Sparger attached at the bottom of the reactor to convert the gas into small bubbles (Chai et al., 2010). Sparging with microbubble allow thorough mixing, $\mathrm{CO}_{2}$ mass transfer and also removes $\mathrm{O}_{2}$ produced during photosynthesis. To observe the influence of light intensity, light photoperiodism and temperature on growth and $\mathrm{CO}_{2}$ fixation, microalgae consortium was cultivated at 2,500 lux and 4,000 lux light intensities. Light intensities were provided by white fluorescent lamps and light photoperiodism (light/dark; hour) were designed to be 24/0, 16/8 and 12/12. Microalgae consortium was then cultivated at $25^{\circ} \mathrm{C}, 30$ ${ }^{\circ} \mathrm{C}$ and $35{ }^{\circ} \mathrm{C}$. During the process of growth in photobioreactor, $2 \%, 5 \%, 7 \%$ pure $\mathrm{CO}_{2}$ was continuously supplied trough the bottom of the photobioreactor, with a flow rate $48 \mathrm{~L} / \mathrm{h}$.

\section{Measurement of growth respond}

Dry weight cell biomass was obtained by evaporating the liquid in the cell culture. A total of $100 \mathrm{~mL}$ culture tube inserted into centrifuges, and then centrifuged at 3,500 rpm for 10 min (Weldy and Huesemann, 2007). Supernatant was then removed from the tube pasta until just earned cells. Pasta cells were then put into a Petri dish that had previously been weighed $(\mathrm{x})$. Samples were put in the oven with a temperature of $105^{\circ} \mathrm{C}$ for one night to get a constant weight $(\mathrm{y})$, and then stored in a desiccator for $30 \mathrm{~min}$ before re-weighed. Biomass (dry weight) according to Torzillo et al. (1991) calculated by the formula: Dry weight $(X ; \mathrm{mg})=y(\mathrm{mg})-\mathrm{x}(\mathrm{mg})$. Specific growth rate $(\mu ; / d)$ was calculated as follows:

$$
\mu=\frac{1}{X} \cdot \frac{d X}{d t}
$$

\section{Measurement of $\mathrm{CO}_{2}$ removal}

Concentration of $\mathrm{CO}_{2}$ in a series of photobioreactor system was measured 2 (two) times a day, using Combination Portable Gas Detector Model RX-515 RIKEN. Measurements were performed to determine changes in the concentration of $\mathrm{CO}_{2}$ in the gas holder with time, whereas the concentration of $\mathrm{CO}_{2}$ dissolved in the culture medium was measured once daily by using acidity alkalinity method to know the solubility of $\mathrm{CO}_{2}$ in the culture medium.

$\mathrm{CO}_{2}$ removal efficiency is the proportion of the absorbed $\mathrm{CO}_{2}$ concentration by the photobioreactor system to $\mathrm{CO}_{2}$ that was supplied. 
$\mathrm{CO}_{2}$ removal efficiency= influent of $\mathrm{CO}_{2}$ - effluent of $\mathrm{CO}_{2} \times 100 \%$ influent of $\mathrm{CO}_{2}$

Carbon Transfer Rate (CTR; $\left.\mathrm{gCO}_{2} / \mathrm{L} . \mathrm{h}\right)$ is the amount of $\mathrm{CO}_{2}$ that is transferred in the medium volume and required by the cell metabolism for a unit of time (Dianursanti, 2012).

$$
\mathrm{CTR}=\Delta\left(\mathrm{yCO}_{2}\right) \cdot \mathrm{aCO} 2
$$

Where,

$\mathrm{aCO}_{2}=$ a constant of $\mathrm{CO}_{2}$ that contains a fixed number of temperature and pressure, airflow superficial velocity; $\Delta\left(\mathrm{yCO}_{2}\right)=$ the concentration change of $\mathrm{CO}_{2}$ in and out of the reactor by the incoming $\mathrm{CO}_{2}$ concentration, multiplied by $100 \%$

$$
\propto_{\mathrm{CO}_{2}}=\frac{\mathrm{U}_{\mathrm{g}} \cdot \mathrm{A} \cdot \mathrm{M}_{\mathrm{CO}_{2}} \cdot \mathrm{P}}{\mathrm{V}_{\text {med }} \cdot \mathrm{R} \cdot \mathrm{T}}
$$

Where, Ug = superficial gas velocity i.e discharge gas fed per reactor cross-sectional area $(\mathrm{m} / \mathrm{h}) ; A=$ surface area of the photobioreactor facing or exposed to light (m2); MCO2 = relative molecular mass of $\mathrm{CO}_{2}(44 \mathrm{~mol}) ; \mathrm{P}=$ operating pressure (1 atm); $\mathrm{V}=$ volume of medium ( $\mathrm{L}) ; \mathrm{R}=$ Rydberg constant $(0.08205$ L.atm $/ \mathrm{mol} . \mathrm{K}) ; \quad \mathrm{T}=$ operating temperature $(0 \mathrm{~K})$.

Carbon fixation rate as specific $\mathrm{CO}_{2}$ transfer rate $\left(\mathrm{qCO}_{2} ; \mathrm{gCO}_{2} . \mathrm{g} /\right.$ cell.h) is the rate of $\mathrm{CO}_{2}$ that is transferred in a medium volume due to the activity of biological life within a unit of time.

$$
\mathrm{q}_{\mathrm{CO}_{2}}=\frac{\Delta \mathrm{y}_{\mathrm{CO}_{2}} \cdot \propto_{\mathrm{CO}_{2}}}{\mathrm{x}}
$$

Where, $\mathrm{X}=$ cell dry weight per unit volume $(\mathrm{g} / \mathrm{L})$.

An approximate formula $\left(\mathrm{CO}_{0.48} \mathrm{H}_{1.83} \mathrm{~N}_{0.11} \mathrm{P}_{0.01}\right)$ suggested by Grobbelaar (2004) was used to make an expected estimate of the dry biomass yield. $\mathrm{CO}_{2}$ utilization efficiency was determined by using the following equation (Ryu et al., 2009):

$$
\begin{aligned}
\mathrm{CO}_{2} \text { utilization efficiency }(\%)= & 0.57 \times \mathrm{P} \times[(44 / 12) / \\
& \left.\mathrm{V}_{\mathrm{CO} 2}\right] \times 100
\end{aligned}
$$

Where, 0.57 is the carbon content of the dry weight cell (gcarbon/gbiomass), 44 and 12 are the molecular weights of carbon dioxide and carbon, $P$ is the productivity ( $g$ biomass/L.h), respectively, and $V$ is the aeration rate of $\mathrm{CO}_{2}$ supplied to the microalgae culture medium ( $\mathrm{g}$ $\mathrm{CO}_{2} /$ L.h).

\section{RESULTS AND DISCUSSIONS}

Effect of light intensity, photoperiodism and temperature were discussed in term of growth response and its relation with $\mathrm{CO}_{2}$ removal.

\section{Effect of light intensities}

At different experimental irradiances, 4,000 lux was found to be the optimum light intensity for biomass production. Whereas a higher light intensity of 5,000 lux caused photo inhibition, therefore microalgae consortium could not grow well since day 1 to day 3 (data not shown). The highest biomass $(2.2 \mathrm{~g} / \mathrm{L})$, and growth rate (0.094/doubling day) was found at 4,000 lux light intensity (Figure 1).

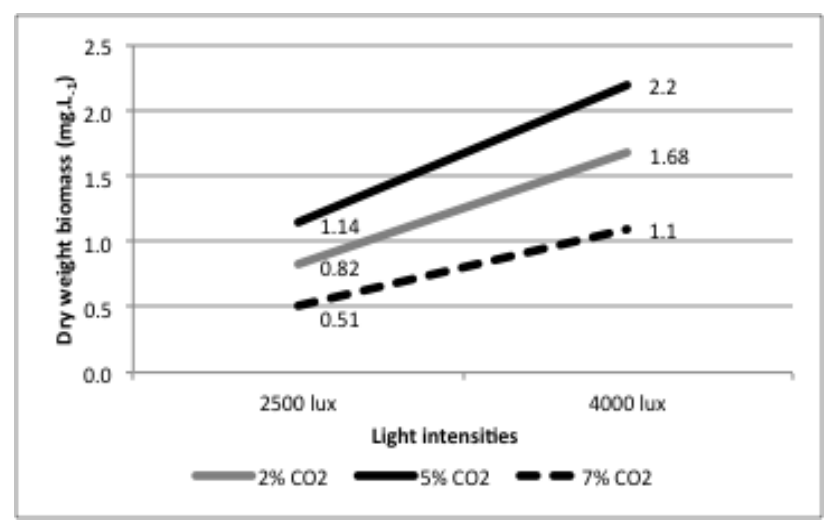

Figure 1: Dry weight biomass of microalgae consortium as a result of light intensities.

It means the biomass increased 2-fold highest compare to cultures in conditions of 2,500 lux. Each type of microalgae requires a certain light intensity for maximum growth (Vonshak et al., 2001). Light intensity played an important role in the excitation of electrons contained in photosystem so photosynthesis could do (Beardall and Raven, 2011). Therefore, the research on the effects of light photoperiodism and temperature would work at 4,000 lux light intensity.

It was crucial to select the optimum cell concentration or optimum dry weight biomass for the efficient $\mathrm{CO}_{2}$ removal. Below the optimum cell concentration, not all the light energy was captured by the cells while at above the optimum cell concentration, a larger proportion of the cell were in the dark due to self-shading (Zhang et al., 2001). Increasing dry weight biomass at 4,000 lux light intensity was followed by increasing 2-fold $\mathrm{CO}_{2}$ removal efficiency compare to $\mathrm{CO}_{2}$ removal efficiency in culture at low light intensity (Table 1). Microalgae density and volume cultivation determine how much light intensity was needed. All algae could take up $\mathrm{CO}_{2}$ by diffusion, and 
Table 1: Average of $\mathrm{CO}_{2}$ removal efficiency, carbon transfer rate and carbon fixation rate as a result of variety light intensities

\begin{tabular}{ccccc}
\hline $\begin{array}{c}\text { Light } \\
\text { intensities }\end{array}$ & $\begin{array}{c}\mathrm{CO}_{2} \\
\text { concentration }\end{array}$ & $\begin{array}{c}\mathrm{CO}_{2} \text { removal efficiency } \\
(\%)\end{array}$ & $\begin{array}{c}\text { Carbon transfer rate } \\
\left(\mathrm{gCO}_{2} / \mathrm{L} . \mathrm{h}\right)\end{array}$ & $\begin{array}{c}\text { Carbon } \\
\text { rate }(/ \mathrm{h})\end{array}$ \\
\hline 2,500 lux & $2 \%$ & 16.05 & 40.43 & 32.62 \\
& $5 \%$ & 19.03 & 35.32 & 25.87 \\
4,000 lux & $7 \%$ & 10.13 & 24.78 & 17.90 \\
& $2 \%$ & 33.58 & 70.72 & 39.50 \\
& $5 \%$ & 39.03 & 81.53 & 38.39 \\
\hline
\end{tabular}

many had active carbon uptake systems which could take up bicarbonate $\left(\mathrm{HCO}_{3}\right)$. However, microalgae could not take up $\mathrm{CO}_{3}{ }^{2-}$ ions (Badger, 2003).

Figure 2 showed that at a concentration of $2 \%$ and $5 \% \mathrm{CO}_{2}, \mathrm{CO}_{2}$ utilization efficiency increased, while it was not working in the concentration of $7 \% \mathrm{CO}_{2}$. It was happened because the compound bicarbonate $\left(\mathrm{HCO}_{3}\right)$ at a concentration of $2 \%$ and $5 \% \mathrm{CO}_{2}$ could still be used by the microalgae to be converted into biomass with the help of CA (carbonic anhydrase), whereas CA activity was decreased in culture supplied by $7 \% \mathrm{CO}_{2}$ so that the effectiveness of the use of bicarbonate compounds catalysed by CA began to decrease.

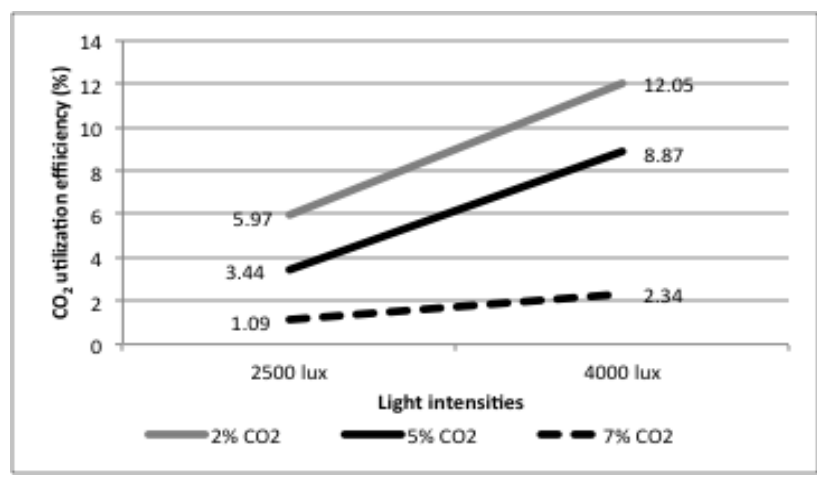

Figure 2: $\mathrm{CO}_{2}$ utilization efficiency of microalgae consortium as a result of light intensities.

The distribution of efficient light throughout the photobioreactor affected the CTR and $\mathrm{qCO}_{2}$ as described in Table 1. Such coefficient is influenced by the superficial velocity (Eq. 4), where superficial velocity $(\mathrm{Ug})$ is the gas volumetric rate divided by the cross-sectional area reactor. In this study, the value of the superficial velocity was $652.23 \mathrm{dm} / \mathrm{d}$ or $27.18 \mathrm{dm} / \mathrm{h}$.

Based on Dianursanti (2012), the superficial velocity was ideally in the range of $12-120 \mathrm{dm} / \mathrm{h}$. Rated 27.18 $\mathrm{dm} / \mathrm{h}$ still in that range, meaning that the use of superficial velocity on the value would not cause a significant change in the volume of the reactor. The researchers Singh and Majumder (2010), suggested that the superficial velocity under $180 \mathrm{dm} / \mathrm{h}$ and the diameter of the water affects the diameter of the bubble gas sparger. High superficial velocity can increase the gas hold-up and bubble surface area (small bubble diameter). Small bubble size caused mass transfer of $\mathrm{CO}_{2}$ working well in this growth medium.

$\mathrm{CO}_{2}$ fixation by microalgae consortium in a vertical bubble column photobioreactor is first marked by a difference in concentration of $\mathrm{CO}_{2}$ that input into the reactor and the concentration of $\mathrm{CO}_{2}$ coming out of the reactor. The difference in $\mathrm{CO}_{2}$ concentration shows that there is a transfer of $\mathrm{CO}_{2}$ from the air into the microalgae cultivation media. The rate of $\mathrm{CO}_{2}$ fixation by microalgae $\mathrm{qCO}_{2}$ is $\mathrm{CO}_{2}$ that is transferred to the medium due to microbiological activity in a unit of time. Carbon fixation rate $\left(\mathrm{qCO}_{2}\right)$ value can be determined based on the CTR values divided by the dry biomass of microalgae.

Table 1 also shows $\mathrm{qCO}_{2}$ value was inversely proportional to the production of dry biomass produced by microalgae. The value of $\mathrm{qCO}_{2}$ is a comparison between the amount of $\mathrm{CO}_{2}$ transferred to the medium and the amount of biomass produced. The greater the value of dry biomass of microalgae, the smaller the value $\mathrm{qCO}_{2}$. It was represented the ability of $\mathrm{CO}_{2}$ fixation by microalgae consortium which was grow well in 4,000 lux light intensity conditions. The efficient distribution of light throughout the photobioreactor affected the carbon dioxide utilization rates.

\section{Effect of light photoperiodism}

Figure 3 showed the difference of light photoperiodism conditions obtained in different dry weight of biomass. Highest biomass dry weight obtained at the condition of the light/dark (16/8), in a culture supplied by $5 \% \mathrm{CO}_{2}$. The increase in $\mathrm{CO}_{2}$ concentration from $2 \%$ to $5 \%$ did not show an increase in dry weight biomass significantly, in dark light conditions (24/0), (16/8), and (12/12). However, the dry weight biomass decreased in all cultures supplied by $7 \% \mathrm{CO}_{2}$, light dark conditions (12/12). This showed that, light dark photoperiodism (24/0) and (16/8) did not cause the increase in dry weight biomass in the culture supplied by $2 \%$ and $5 \% \mathrm{CO}_{2}$ significantly.

Ryu et al. (2009) analyzed the impact of $\mathrm{CO}_{2}$ concentration in vertical tubular reactors without controlling the temperature of the system. According to their findings, a maximum cell concentration of $2.02 \mathrm{~g} / \mathrm{L}$ was found at $5 \% \mathrm{CO}_{2}$ and the minimum cell concentration of $1.16 \mathrm{~g} / \mathrm{L}$ was found at $0.5 \% \mathrm{CO}_{2}$ mixed in air. They suggested keeping the $\mathrm{CO}_{2}$ concentration lower than $5 \%$ because higher $\mathrm{CO}_{2}$ concentrations might inhibit microalgae growth. The other researchers Chiu et al. 
(2009) demonstrated that the $\mathrm{CO}_{2}$ removal efficiency in the porous centric-tube photobioreactor is 45 and $52 \%$ was higher than those in the bubble column and centrictube photobioreactors, respectively.

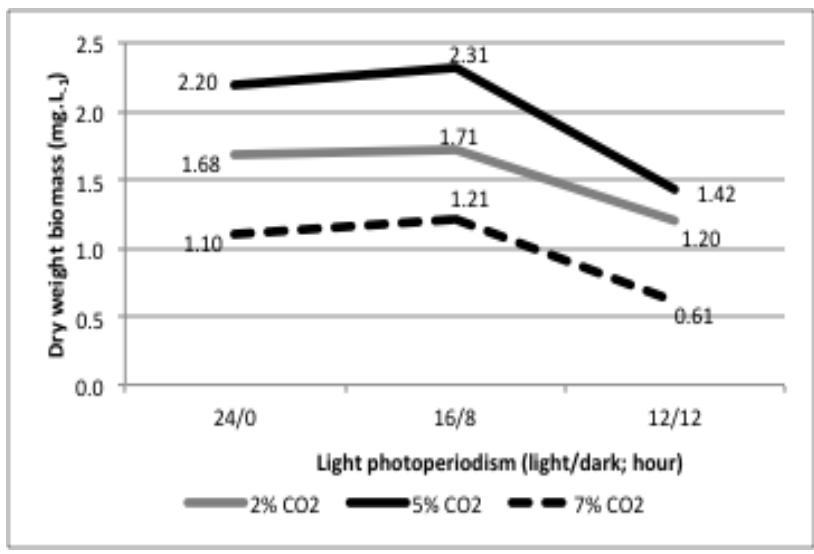

Figure 3: Dry weight biomass of microalgae consortium as a result of light photoperiodism.
Table 2 showed that same thing with biomass dry weight, light dark conditions (24/0) and (16/8) did not show the increase in $\mathrm{CO}_{2}$ removal efficiency significantly by increasing $2 \%$ to $5 \% \mathrm{CO}_{2}$ concentration. However, in the light-dark conditions (16/8) obtained $\mathrm{CO}_{2}$ removal efficiency 2 -fold higher than in dark light conditions (12/12). This suggested that the removal of $\mathrm{CO}_{2}$ in microalgae photobioreactor system was affected by the length of the sufficient light. For efficiency of energy sources derived from artificial light, the next experiments did not use dark light conditions (24/0) but instead, using light dark conditions (16/8).

$\mathrm{CO}_{2}$ utilization efficiency differences between light and dark conditions can be seen in Figure 4 In long dark periods (12/12), microalgae could not do biomass synthesis process completely. Cell respiration was more dominant so that the culture medium became saturated with carbonate compounds that were not utilized by microalgae. As a result, the process of transfer of $\mathrm{CO}_{2}$ into the cell microalgae decreased. In this experiment, $\mathrm{CO}_{2}$ utilization efficiency in light-dark conditions (12/12) only reaches half its efficiency that showed in the shorter dark conditions ( $8 \mathrm{~h}$ of dark). This was the case in all variation of $\mathrm{CO}_{2}$ concentrations.

Table 2: Average of $\mathrm{CO}_{2}$ removal efficiency, carbon transfer rate and carbon fixation rate as a result of variety light photoperiodism.

\begin{tabular}{ccccc}
\hline $\begin{array}{c}\text { Light photoperiodism } \\
\text { (light/dark; } \mathrm{h})\end{array}$ & $\begin{array}{c}\mathrm{CO}_{2} \\
\text { concentration }\end{array}$ & $\begin{array}{c}\mathrm{CO}_{2} \text { removal } \\
\text { efficiency }(\%)\end{array}$ & $\begin{array}{c}\text { Carbon transfer rate } \\
\left(\mathrm{gCO}_{2} / \mathrm{L} . \mathrm{h}\right)\end{array}$ & $\begin{array}{c}\text { Carbon fixation rate } \\
(/ \mathrm{h})\end{array}$ \\
\hline $24 / 0$ & $2 \%$ & 33.58 & 70.72 & 39.50 \\
& $5 \%$ & 39.03 & 81.53 & 38.39 \\
$16 / 8$ & $7 \%$ & 18.05 & 39.85 & 24.48 \\
& $2 \%$ & 36.33 & 76.35 & 36.52 \\
$12 / 12$ & $5 \%$ & 43.13 & 90.24 & 39.84 \\
& $7 \%$ & 21.03 & 44.63 & 38.39 \\
& $2 \%$ & 20.49 & 43.46 & 29.90 \\
& $5 \%$ & 22.80 & 48.32 & 20.23 \\
\hline
\end{tabular}

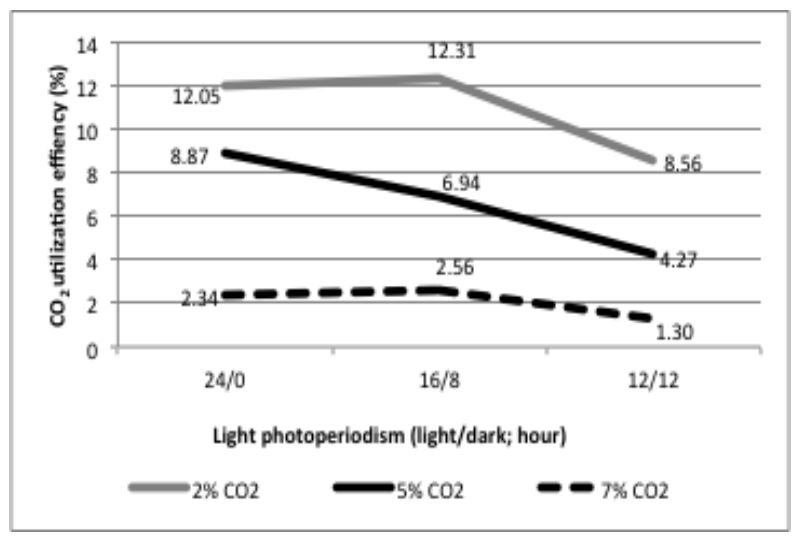

Figure 4: $\mathrm{CO}_{2}$ utilization efficiency of microalgae consortium as a result of light photoperiodism.
CTR values increased since the beginning of the growth period, when the concentration of $\mathrm{CO}_{2}$ in the culture medium was below the threshold of saturation, so the $\mathrm{CO}_{2}$ gas more soluble in the culture medium (Table 2). Trend curves CTR during cultivation is look like shown in Figure 5. In addition, the increase of cell density and dry weight biomass enhanced the absorption of gas dissolved in the form of $\mathrm{HCO}_{3}^{-}$by microalgae. CTR tended to decrease over time at day 10 due to the imbalance between increasing of cells densities and $\mathrm{CO}_{2}$ biofixation. This condition eventually caused biomass production constant and finally decreased.

Table 2 also shows the values $\mathrm{qCO}_{2}$ inversely proportional to the value of biomass dry weight during cultivation. The higher growth of microalgae correlated with the smaller value of $\mathrm{qCO}_{2}$. It was happened because the increased biomass production resulted in less $\mathrm{CO}_{2}$ available that could be fixed by the cells. Therefore the rate of $\mathrm{CO}_{2}$ fixation decreased. 


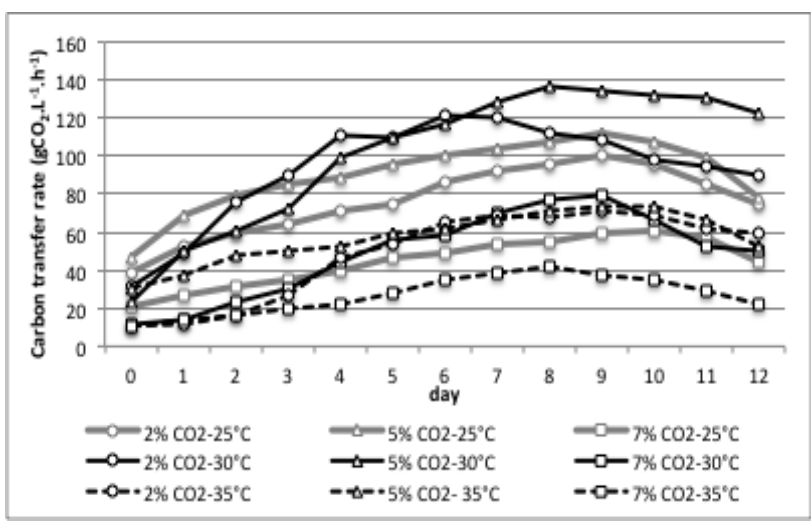

Figure 5: Carbon transfer rate as a result of variety temperature.

The same observation applied to the value of the CTR. The average value of $\mathrm{qCO}_{2}$ in condition light/ $(24 / 0)$ of 39 $\mathrm{h}$ did not differ significantly compare with light/dark of (16/8). While in condition of light/ dark (12/12) the values of $\mathrm{qCO}_{2}$ was only $29 / \mathrm{h}$. Differences in $\mathrm{qCO}_{2}$ values for both conditions was caused by the fact that microalgae did not take carbon source of the $\mathrm{CO}_{2}$ entering the reactor in dark conditions.

The average CTR at light-dark conditions (16/8) reached $90 \mathrm{~g} / \mathrm{L}$.h. The value did not differ significantly compare with light-dark conditions (24/0). However in light-dark conditions $(12 / 12)$ the value of CTR was observed only $48 \mathrm{~g} / \mathrm{L} . \mathrm{h}$ (Table 2). CTR values for the two conditions were significantly different because in dark conditions microalgae was not experiencing the full growth cycle. Respiration processes occurred predominantly intra-cellular, so that transfer of carbon from the $\mathrm{CO}_{2}$ entering the reactor greatly reduced. This phenomenon led to the transfer of $\mathrm{CO}_{2}$ in the light-dark conditions (12/12) was observed to be smaller than in the light-dark conditions either (24/0) or (16/8).

Until the end of the study, culture supplied with $7 \%$ $\mathrm{CO}_{2}$ gave the most unfavorable response compared with $2 \%$ and $5 \% \quad \mathrm{CO}_{2}$. High $\mathrm{CO}_{2}$ concentrations (>5\%) generally become toxic to microalgae, presumably because the medium becomes acidic from carbonic acid.

\section{Effect of increasing temperature}

Biomass productivity of constructed consortium was evaluated at various temperatures $\left(25^{\circ} \mathrm{C}, 30^{\circ} \mathrm{C}\right.$, and 35 $\left.{ }^{\circ} \mathrm{C}\right)$ for a period of 12 days. Growth analysis of cultures grown at different temperatures showed significant differences $(p<0.05)$ in growth pattern. Maximum biomass concentration (as dry weight) ie. 2.70 $\mathrm{g} / \mathrm{L}$ was observed at temperature $30^{\circ} \mathrm{C}$ and least i.e. $2.11 \mathrm{~g} / \mathrm{L}$ was found at temperature $25{ }^{\circ} \mathrm{C}$ (Figure 6). Growth curve of cultures at various temperatures revealed that green microalgae species had a wide range of temperature tolerance, ranging from $20^{\circ} \mathrm{C}$ to $40{ }^{\circ} \mathrm{C}$. In this experiment, cultures at $40{ }^{\circ} \mathrm{C}$ did not show exponential growth. The growth was almost negligible (data not recorded). The maximum growth rate ie. 0.38/ doubling day was observed at $30{ }^{\circ} \mathrm{C}$, but with further increase in temperature reduction in growth rate was observed. At $35{ }^{\circ} \mathrm{C}$ culture showed 0.12 /doubling day which was almost $30 \%$ slower as compare to growth rate at $30^{\circ} \mathrm{C}$. It was proved that extreme temperatures did not support the growth of mix culture.

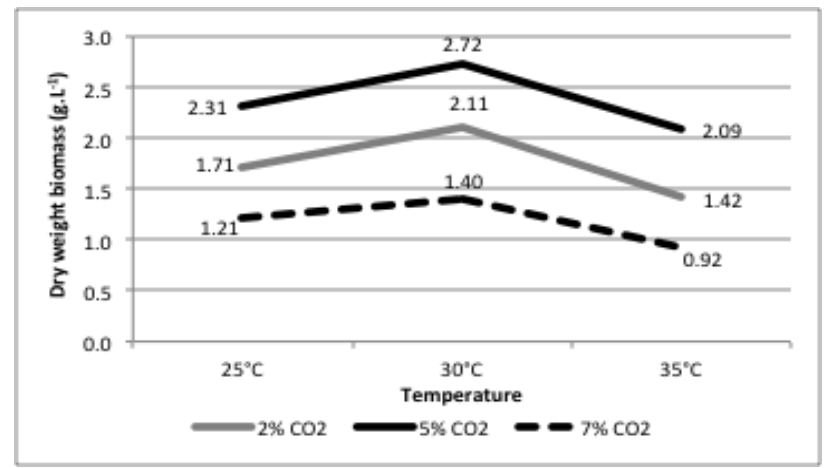

Figure 6: Dry weight biomass of microalgae consortium as a result of temperature.

The experiment also demonstrated that there were increased in dry weight biomass and $\mathrm{CO}_{2}$ removal efficiency (Figure 6 and Table 3 ) ranging from 2 to 2.5 times higher than the initial conditions (Figure 1 and Table 1) in all variations of $\mathrm{CO}_{2}$ concentrations. $\mathrm{CO}_{2}$ removal efficiency by microalgae was influenced by several factors, such as $\mathrm{CO}_{2}$ concentration and flow rate (Ryu et al., 2009), light intensity (Perner-Nochta and Posten, 2007), lightfotoperiodism (Lopes et al., 2008), cell density (Jiang et al., 2011), temperature (Chinnasamy, 2009), and the type of reactor (Kumar et al., 2010).

Increasing temperature up to $30{ }^{\circ} \mathrm{C}$ also increased $\mathrm{CO}_{2}$ utilization efficiency to over 5-fold (Figure 7) compared to initial conditions (Figure 2). However at a temperature of $35^{\circ} \mathrm{C}$ efficiency was decreased.

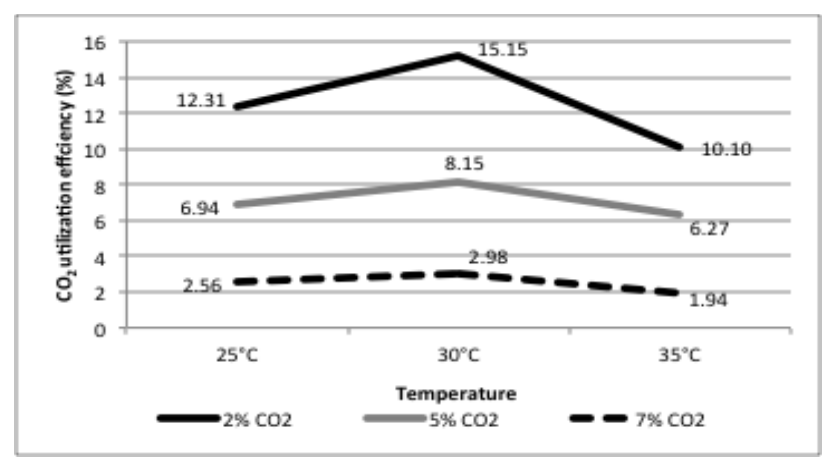

Figure 7: $\mathrm{CO}_{2}$ utilization efficiency of microalgae consortium as a result of temperature.

As temperature increased, the rate of photosynthesis increased more rapidly until the optimum temperature reached. Above the optimum temperature the rate of 
Table 3: Average of $\mathrm{CO}_{2}$ removal efficiency, carbon transfer rate and carbon fixation rate as a result of variety temperature.

\begin{tabular}{ccccc}
\hline Temperature & $\begin{array}{c}\mathrm{CO}_{2} \\
\text { concentration }\end{array}$ & $\begin{array}{c}\mathrm{CO}_{2} \text { removal } \\
\text { efficiency }(\%)\end{array}$ & $\begin{array}{c}\text { Carbon transfer rate } \\
\left(\mathrm{gCO}_{2} / \mathrm{L} . \mathrm{h}\right)\end{array}$ & $\begin{array}{c}\text { Carbon fixation rate } \\
(/ \mathrm{h})\end{array}$ \\
\hline $25{ }^{\circ} \mathrm{C}$ & $2 \%$ & 36.33 & 76.35 & 36.90 \\
& $5 \%$ & 43.13 & 90.24 & 35.54 \\
$30{ }^{\circ} \mathrm{C}$ & $7 \%$ & 21.03 & 44.63 & 30.70 \\
& $2 \%$ & 42.95 & 93.17 & 40.08 \\
$35{ }^{\circ} \mathrm{C}$ & $5 \%$ & 49.02 & 101.29 & 42.02 \\
& $7 \%$ & 23.18 & 48.55 & 38.21 \\
& $2 \%$ & 23.94 & 48.46 & 34.22 \\
& $5 \%$ & 28.13 & 57.30 & 22.36 \\
\hline
\end{tabular}

photosynthesis dropped significantly. This was because of fixation of $\mathrm{CO}_{2}$ that was catalyzed by enzymes, which faster at higher temperatures. Nevertheless the enzyme denatured in high temperature. This explained why at 35 ${ }^{\circ} \mathrm{C}$ the $\mathrm{CO}_{2}$ utilization efficiency was decreased (Figure 7).

Carbon fixation rate also slower than culture condition at $30^{\circ} \mathrm{C}$ (Figure 8) and then at $40^{\circ} \mathrm{C}$ the growth was almost negligible (data not recorded). Although average of $\mathrm{CTR}$ values obtained from $30{ }^{\circ} \mathrm{C}$ conditions seemed to be higher than $25^{\circ} \mathrm{C}$ condition, however the difference was not significant (Table 3). CTR values obtained at a temperature of $30^{\circ} \mathrm{C}$ reached 2 -fold higher than the CTR value obtained at $35^{\circ} \mathrm{C}$ conditions (Table 3). Compared to the initial conditions (Table 1, 2,500 lux), the CTR values obtained in all variation of $\mathrm{CO}_{2}$ concentrations, increased by approximately 2 -fold (occurred in culture which were supplied by $2 \%$ and $5 \%$ $\mathrm{CO}_{2}$ ) and reached 2.8-fold obtained in culture which was supplied with $5 \% \mathrm{CO}_{2}$. This proved that the value of CTR was affected by the temperature in the photobioreactor. However the density of microalgae consortium did not give any effect. Despite the growth of microalgae increased, carbon transfer in the growth medium was not inhibited. Trend curves CTR during cultivation is look like shown in Figure 5.

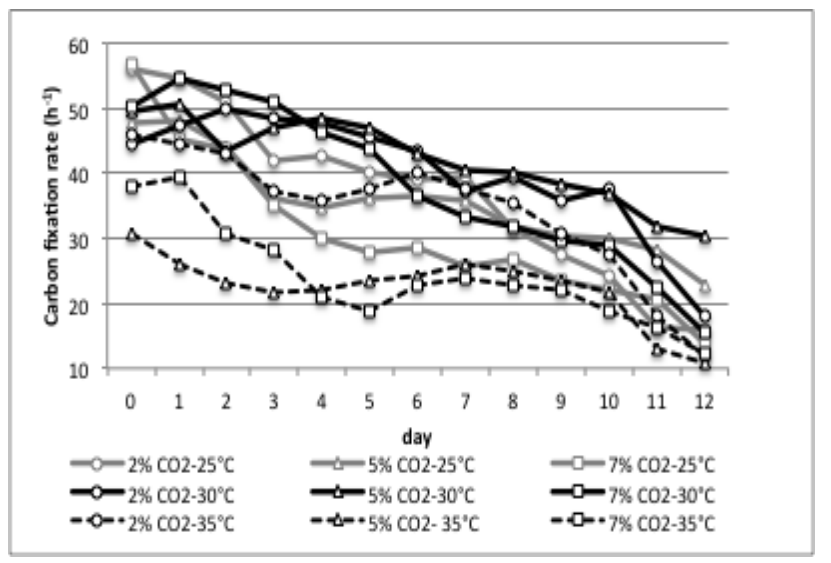

Figure 8: Carbon fixation rate as a result of variety temperature.
The optimum temperature for the growth of microalgae was $25-400{ }^{\circ} \mathrm{C}$ (Hanagata et al., 1992; Vonshak et al., 2001; Chinnasamy, 2009). Temperature affected the processes of physics, chemistry and biology that were happening in the microalgae cells. Increasing the temperature up to a certain limit would stimulate the activity of the molecule, increasing the rate of diffusion and the rate of photosynthesis (Badger, 2003).

Although at $7 \% \mathrm{CO}_{2}$ concentration all the results of this study showed lower value than the culture that were supplied by $2 \%$ and $5 \%$ of $\mathrm{CO}_{2}$, however microalgae consortium remained able to growth and utilize the high $\mathrm{CO}_{2}$ concentration $\left(7 \% \mathrm{CO}_{2}\right)$.

\section{CONCLUSION}

Controlling environmental parameters could improve the ability of microalgae to remove $\mathrm{CO}_{2} . \mathrm{CO}_{2}$ removal efficiency was highest when microalgae consortium cultivated in 4,000 lux light intensity, periods of light/dark (16/8), and temperature $30{ }^{\circ} \mathrm{C}$. Microalgae consortium demonstrated optimum capacity to remove $\mathrm{CO}_{2}$ at $5 \%$ $\mathrm{CO}_{2}$ supplied. This was evidenced by dry weight of biomass which was 2.5 times higher, $\mathrm{CO}_{2}$ removal efficiency above 2.5 times higher and the $\mathrm{CO}_{2}$ utilization efficiency over 5 times higher. In addition, carbon transfer rate also increased. All results were compared with initial condition (2,500 lux, light/dark (24/0), $\left.25{ }^{\circ} \mathrm{C}\right)$. Nevertheless carbon fixation rate did not increase significantly. It is interesting to see if supplying a higher $\mathrm{CO}_{2}$ concentration would also increase capacity of $\mathrm{CO}_{2}$ removal by microalgae consortium. This remains to be investigated in further research.

\section{ACKNOWLEDGEMENT}

The author would like to thank DIKTI (Directorate General of Higher Education Indonesia) Program of Decentralization 2012 for funding some of this research.

\section{REFERENCES}

Badger, M. (2003). The roles of carbonic anhydrases in photosynthetic $\mathrm{CO}_{2}$ concentrating mechanisms. Photosynthesis Research 77(2-3), 83-94. 
Beardall, J. and Raven, J. A. R. (2011). Limits to phototrophic growth in dense culture: $\mathrm{CO}_{2}$ supply and light. In: Algae for Biofuels and Energy. Borowitzka, M. (ed). Springer, Berlin. pp. 221-245.

Carlozzi, P. (2003). Dilution of solar radiation trough "culture" lamination in photobioreactor rows facing south-north: A way to improve the efficiency of light utilization (Arthrospira platensis). Biotechnology and Bioengineering 81(3), 305-315.

Chai, X., Zhao, X. and Baoying, W. (2010). Biofixation of carbon dioxide by Chlorococcum sp. in a photobioreactor with polytetrafluoroethene membrane sparger. African Journal of Biotechnology 11 (29), 7445-7453.

Chinnasamy, S., Ramakrishahman, B., Bharnagar, A. and Das, K. C. (2009). Biomass production potential of a freshwater alga Chlorella vulgaris arc 1 under elevated $\mathrm{CO}_{2}$ and temperature. International Journal of Molecular Sciences 10, 518-532.

Chisti, Y. (2007). Biodiesel from microalgae. Biotechnology Advances 25(3), 294-306.

Chiu, S. Y., Tsai, M. T., Kao, C. Y., Ong S. C. and Lin, C. S. (2009). The air-lift photobioreactors with flow patterning for high-density cultures of microalgae and carbon dioxide removal. Engineering in Life Science 9(3), 254-260.

Dianursanti (2012). Development of Chlorella vulgaris biomass production system in a flat plate reactor through lighting optimization using filtration technique in culture media flow. Dissertation. Chemical Enginnering, Technical Faculty, Indonesia University, Indonesia.

Grobbelaar, J. U. (2004). Algal nutrition. Mineral nutrition. In: Handbook of Microalgae Culture: Biotechnology and Applied Phycology. Richmond A. (ed.). Blackwell Publishing, Oxford, UK 97-115.

Hanagata, N., Takeuchi, T., Fukuju, Y., Barnes D. J. and Karube, I. (1992). Tolerance of microalgae to high $\mathrm{CO}_{2}$ and high-temperature. Phytochemistry 31(10), 3345-3348.

Jiang, R., Luo, S., Fan, X., Yang, Z. and Guo, R. (2011). Biomass and lipid concentration using municipal wastewater and high concentration of $\mathrm{CO}_{2}$. Applied Energy 88(10), 3336-3341.

Kumar, A., Ergas, S., Yuan, X., Sahu, A., Zhang, Q., Dewulf, J., Malcata, X. F., and Langenhove, $H$. (2010). Enhanced $\mathrm{CO}_{2}$ fixation and biofuel production via microalgae: Recent developments and future directions. Trends in Biotechnology 28(7), 371-380.

Lopes, J. E., Scoparo, C., Lacerda, L. and Fraco, T. (2008). Effect of light cycles (night/day) on $\mathrm{CO}_{2}$ fixation and biomass production by microalgae in photobioreactors. Chemical Engineering and Process Intensification 48(1), 306-310.

Madigan, M. T., Martinko, J. M. and Parker, J. (2000). Brock Biology of Microorganisms. $9^{\text {th }}$ ed. Prentice Hall, Upper Saddle River, New Jersey, U.S.

Masojídek, J., Kopecký, J., Gianelli, L. and Torzillo, G. P. (2011). Productivity correlated to photochemical performance of Chlorella mass cultures grown outdoors in thin-layer cascades. Journal of Industrial Microbiology and Biotechnology 38(2), 307-317.

Moheimani, N. R. (2005). The culture of coccolithophorid algae for carbon dioxide bioremediation. Dissertation. Murdoch University, Australia,

Muñoz, R. and Guieysse, B. (2006). Algal-bacterial processes for the treatment of hazardous contaminants: A review. Water Research 40(15), 2799-2815.

Perner-Nochta, I. and Posten, C. (2007). Simulations of light intensity variation in photo-bioreactors. Journal of Biotechnology 131(3), 276-285.

Provasoli, L. and Pintner, I. J. (1960). Artificial media for freshwater algae: Problems and suggestions. In: The Ecology of Algae. Tryon, C. A. and Hartman, R.T. (ed.). Special Publication No. 2. Pymatuning Laboratory of Field Biol., University Pittsburgh, USA.

Rinanti, A., Kardena, E., Astuti, D. I. and Dewi, K. (2013). Increasing the efficiency of carbon dioxide removal by synergizing constructed green microalgae consortium using photobioreactor. In: Proceeding in the Second International Conference on Sustainable Infrastructure and Built Environment, Bandung, Indonesia.

Rubio, F. C., Camacho, F. G., Sevilla, J. M. F., Chisti, Y. and Grima, E. M. (2003). A mechanistic model of photosynthesis in microalgae. Biotechnology and Bioengineering 81(4), 459-473.

Ryu, H. J., Oh, K. K. and Kim, Y. S. (2009). Optimization of the influential factors for the improvement of $\mathrm{CO}_{2}$ utilization efficiency and $\mathrm{CO}_{2}$ mass transfer rate. Journal of Industrial and Engineering Chemistry 15(4), 471-475.

Singh, M. K. and Majumder, S. K. (2010). Theoretical studies on effect of operating parameters on mass transfer in bubbly flow. Journal of Engineering and Applied Sciences 5(2), 160-173.

Striebal, M., Behl, S. and Stiber, H. (2009). The coupling of biodiversity and productivity and phytoplankton communities consequences of biomass. Ecology 90(8), 2025-2031.

Thébault, J. M. and Rabouille, S. (2003). Comparison between two mathematical formulations of the phytoplankton specific growth rate and temperature, in two stimulation models (Aster \& Yoyo). Ecological Modeling 163(1-2), 145-151.

Torzillo, G., Sacchi, A. and Materassi, R. (1991). Temperature as an important factor affecting productivity and night biomass loss in Arthrospira (Spirulina) platensis grown outdoors in tubular phtobioreactors. Bioresource Technology 38, 95100.

Vonshak A., Torzillo G., Masojidek J. and Boussiba S. (2001). Sub-optimal morning temperature induces photoinhibition in dense outdoor cultures of the algal Monodus subterraneus (Eustigmatophyta). Plant, Cell and Environment 24(10), 1113- 1118. 
Wang, B., Li, Y., Wu, N. and Lan, C. Q. (2008). $\mathrm{CO}_{2}$ biomitigation using microalgae.Applied Microbiology and Biotechnology 79(5), 707-718.

Weldy, C. S. and Huesemann, M. (2007). Lipid production by Dunaliella salina in batch culture: Effects of nitrogen limitation and light intensity. US Department of Energy Journal of Undergraduate Research 7(1), 115-122.

Zhang, K., Miyachi, S. and Kurano, N. (2001). Valuation of a vertical flat-plate photobioreactor for outdoor biomass production and carbon dioxide biofixation: Effects of reactor dimensions, irradiation and cell concentration on the biomass productivity and irradiation utilization efficiency. Applied Microbiology and Biotechnology 55(4), 428-433. 